\title{
Candidate Species for Florida Aquaculture: Arapaima Arapaima gigas $^{1}$
}

\author{
Cortney L. Ohs, Jeffrey E. Hill, Sarah E. Wright, H. Mae Giddings, and Allison L. Durland \\ Donahou ${ }^{2}$
}

\section{Abstract}

Arapaima Arapaima gigas, also known as paiche and pirarucu, is a large South American freshwater fish with unique biology and favorable aquaculture characteristics that has potential for aquaculture in south Florida. This publication highlights Arapaima gigas biology and the specific culture methods known for each stage of development. Additionally, disease and parasites, markets, and the laws associated with this species are covered. The goal of this publication is to provide valuable information to potential arapaima producers in the southeastern United States so they can make informed business decisions.

\section{General Description}

Arapaima Arapaima gigas, also known as paiche and pirarucu, is a large tropical South American freshwater fish in the order Osteoglossiform. Arapaima are distinctly shaped with a compressed body, homocercal caudal fin, and posteriorly positioned dorsal and anal fins (Berra 2001). Adult arapaima are olive-brown dorsally, transitioning to silver-gray ventrally. The posterior margin of the scales shows distinctive red pigmentation (Figure 1). Arapaima can attain lengths of more than $3.3 \mathrm{~m}$ (10.8 feet) and weights greater than $200 \mathrm{~kg}$ (484 pounds) (Nuñez 2012).

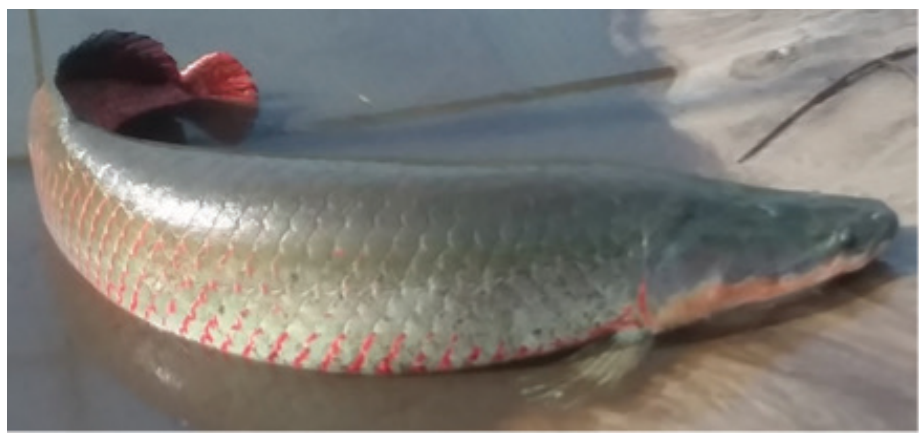

Figure 1. Arapaima Arapaima gigas.

Credits: Allison Durland Donahou, Tropical Aquaculture Laboratory

Arapaima are obligate air breathers, meaning they must breathe air because they do not absorb sufficient oxygen through their gills, which are proportionally small for their body mass. The swim bladder is the primary respiratory organ. This allows arapaima to tolerate hypoxic water uninhabitable by other fish with dissolved oxygen (DO) concentrations as low as $0.5 \mathrm{mg} / \mathrm{L}$ (de Quiroz 2000). Arapaima cultured in low density will tolerate DO levels as low as $0.9 \mathrm{mg} / \mathrm{L}$, whereas arapaima in high density require DO levels of at least $1.4 \mathrm{mg} / \mathrm{L}$, however higher DO levels are recommended (Arantes et al. 2013). Arapaima have been recorded in tropical habitats with widely varying water parameters, which are outlined in Table 1.

1. This document is FA236 one of a series of the School of Forest, Fisheries, and Geomatics Sciences Program in Fisheries and Aquatic Sciences. Original publication date June 2021. Visit the EDIS website at https://edis.ifas.ufl.edu for the currently supported version of this publication.

2. Cortney L. Ohs, associate professor, School of Forest, Fisheries, and Geomatics Sciences and aquaculture specialist, UF/IFAS Florida Sea Grant, UF/ IFAS Indian River Research and Education Center; Jeffrey E. Hill, professor, School of Forest, Fisheries, and Geomatics Sciences, Tropical Aquaculture Laboratory; Sarah E. Wright, student, University of Illinois College of Veterinary Medicine; H. Mae Giddings, graduate, Master of Fisheries and Aquatic Sciences program, School of Forest, Fisheries, and Geomatics Sciences; and Allison L. Durland Donahou, graduate, School of Natural Resources and Environment, Tropical Aquaculture Lab; UF/IFAS Extension, Gainesville, FL 32611.

The Institute of Food and Agricultural Sciences (IFAS) is an Equal Opportunity Institution authorized to provide research, educational information and other services

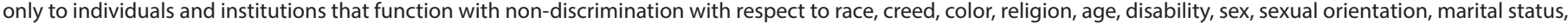
national origin, political opinions or affiliations. For more information on obtaining other UF/IFAS Extension publications, contact your county's UF/IFAS Extension office. U.S. Department of Agriculture, UF/IFAS Extension Service, University of Florida, IFAS, Florida A \& M University Cooperative Extension Program, and Boards of County Commissioners Cooperating. Nick T. Place, dean for UF/IFAS Extension. 
Unlike other elongate fish, arapaima have no intramuscular rib bones. This characteristic yields high-quality bone-free fillets, which are $50-55 \%$ of the body weight of harvested fish (Guerra et al. 2002). Despite being predatory, arapaima adapt well to commercially available pelleted food in a variety of aquaculture settings and have shown feed conversion ratios of 1.7-2.3. Arapaima reach market size rapidly after approximately twelve months of age, depending on feeding intensity. The resulting fillets are $50-55 \%$ of the arapaima's pre-harvest body weight. These attributes, combined with variable exports of arapaima meat from South America and the suitable climate in southern Florida, make the arapaima a good candidate species for Florida aquaculture.

\section{Distribution and Habitat}

Arapaima are native to the Amazon River basin. Arapaima are non-native to the south Peruvian (Madre de Dios) and Bolivian areas of the basin, but they were unintentionally introduced intothe Ucayali River basin of Peruin the 1970s. Arapaima have also been introduced to China, Cuba, Mexico, Philippines, Singapore, and Thailand. Arapaima aquaculture in these areas is not as established as in South America, but it has been expanding. The air-breathing capabilities of arapaima allow them to exploit a variety of habitats. Arapaima migrate laterally into the flooded forest during the rainy season, from November to May, and preferentially inhabit large oxbow lakes and deep river channels during the dry season from June to October.

\section{Natural History}

Arapaima are most abundant in tropical rainforest floodplains seasonally flooded by sediment-laden rivers. This habitat comprises approximately $2 \%$ of the Amazon basin. Adult arapaima prefer a lake of at least three hectares for every three fish. Arapaima are ambush predators who engulf smaller fish by creating suction in their buccal cavity. Arapaima are secondary consumers (i.e., not apex predators) feeding primarily on fish such as loricariid, callichthyid, and pimelodid catfish, knifefish, and characins. They may opportunistically prey on small birds, reptiles, and mammals. Large adult arapaima have few predators; jaguars, caimans, and humans may hunt them opportunistically during the dry season (de Queiroz 2000).

Arapaima form pairs during the rainy season and construct a nest on hard bottom, in clear shallow water, with overhead shade. The female deposits an adhesive emerald green egg mass into the nest that is then fertilized by the male. Both parents guard the eggs and larvae, which remain in the nest for several days. After the yolk sac is absorbed, fingerlings leave the nest and shoal around the male, while the female guards the nesting territory. Arapaima provide parental care for approximately one month, after which the fingerlings disperse (Guerra et al. 2002).

Young arapaima inhabit confined nursery habitats that diminish as rivers recede during the dry season. Arapaima juveniles are olive colored with a blotchy pattern, which they retain until approximately one year. The youngest juvenile arapaima possess large, comb-like gill rakers for suspension feeding on zooplankton. Arapaima under $50 \mathrm{~cm}$ (20 inches) total length (TL) have a varied diet including insects, fish, crustaceans, and mollusks. Arapaima in the $51-180 \mathrm{~cm}$ (20-71 inches) size class feed primarily on smaller fish. Mollusks, especially apple snails (Ampullariidae), are a major component of the diet of juvenile arapaima in the $181-200 \mathrm{~cm}$ (71-79 inches) TL size class. The predators of juvenile arapaima include aquatic birds, piranha (Pygocentrus sp.), wolf fish (Erythrinus erythrynus), tucanare peacock bass (Cichla monoculus), and oscar (Astronotus ocellatus). The details of arapaima natural history, especially trophic interactions, should be considered in future risk assessments for Florida aquaculture, as well as in the development of feeding regimens and broodstock protocols.

\section{Conservation Issues}

The conservation status of arapaima, as well as recent shifts in taxonomy discussed in the next section, present unique challenges to the development of aquaculture commerce for this species. Arapaima are an important component of local biodiversity in South America and are intimately tied to the culture and economy of the people of the Amazon River basin. Traditionally, arapaima were hunted for food and trade. However, arapaima became overfished, presenting a conservation concern (de Queiroz 2000). Arapaima (Arapaima gigas) are a CITES Appendix II listed species. Appendix II species are not necessarily threatened with extinction; however, it is recommended that trade be controlled to avoid utilization incompatible with their survival. This poses a unique challenge to the development of aquaculture commerce for this species.

To mitigate conservation concerns, international trade of arapaima is restricted by non-detriment finding procedures. Cultured arapaima may be traded internationally if an export or re-export certificate is obtained. These certificates are issued by the management authority of the state of export. Additionally, an export permit may be issued only if the arapaima was legally obtained and if the export will not 
be detrimental to the survival of the species; and a re-export certificate may be issued only if the specimen was imported in accordance with the CITES. Also, live arapaima must be prepared and shipped to minimize any risk of injury, damage to health, or cruel treatment, and no import permit is necessary unless required by national law. No-take zones and aquatic protected areas have also been established in areas reported as arapaima nurseries. Additional regulatory measures include a fishing ban during the arapaima mating season (October to February) in South America, a fingerling repopulation and management program in the Ucayali Riverregion, and culture of arapaima.

\section{Taxonomy}

Arapaima area fish in the order Osteoglossiform in the family Arapamidae and the genus Arapaima. Historically, Arapaima was thought to be a monotypic genus. Re-descriptions of previously described taxa show that the genus Arapaima is comprised of five species: A. gigas, A. mapae, A. agassizii, A. arapaima, and A. leptosome. Arapaima gigas is currently the only species that is listed as endangered.

\section{Culture Methods}

Until recently, culture has been non-intensiveand generally conducted in ponds, embayments, or reservoirs. Semi-intensive methods are currently the focus of most research and development, while the feasibility of intensive culturemethods requires further investigation.

One of the greatest concerns regarding development ofarapaima aquaculture in Florida is the potential for arapaima to become invasive in the event of escape. Hill et al. (2015) found that current regulations provide appropriate risk mitigation for arapaima culture in Florida. Additionally, Lawson et al. (2015) established that the lower lethal temperature for arapaima is $16^{\circ} \mathrm{C}$, indicating that survival of escaped fish would be highly unlikely in northern Florida. From a commercial standpoint, this finding also indicates that there is limited potential for outdoor arapaima aquaculture in northern Florida, but there is still potential in southern Florida.

\section{Breeding and Broodstock}

Arapaima broodstock husbandry has been investigated in Brazil since the 1930s and is an area of ongoing research in South America. The general reproductive cycle of arapaima is understood, but there is little control in the current extensive and semi-intensive aquaculture practices. There are currently no published studies regarding the use of hormones for greater control of production cycles. Using hormones on such large fish is most likely impractical outside of an intensive culture operation. Arapaima spawn with the greatest frequency from December to March during the rainy season in South America but have been reported to spawn year-round in culture situations. Arapaima broodstock are typically $4-5$ years old, $1.60-1.85 \mathrm{~m}$ (5.25-6.0 feet) long, and weigh $40-60 \mathrm{~kg}$ (88-132 pounds) (Nuñez et al. 2011). Shaded areas are preferred nesting sites for wild arapaima, and this should be considered when selecting/constructing breeding ponds. It is possible that shade has a vital role in maintaining a stable water temperature during incubation. Arapaima that are exposed to UVA/UVB light have been shown to have health problems, which is a further indication that providing shade is a necessary part of arapaima broodstock husbandry (Groff et al. 2010). After breeding pairs are determined, they are placed in shallow, earthen bottomed breeding ponds. The suggested water quality parameters are outlined in Table 1. Recommended stocking densities are one adult arapaima for every $100-300 \mathrm{~m}^{2}$ (1076.39-3229.17 square feet) of pond surface area (Guerra et al. 2002). Although there was no significant difference in fingerling production from pairs of arapaima kept in in $350-800 \mathrm{~m}^{2}$ (3767.37-8611.13 square feet) breeding ponds (Rebouças et al. 2014).

Arapaima form breeding pairs consisting of a single male and female. Sexing is necessary for breeding pair selection in commercial aquaculture, but arapaima are difficult to sex visually because they do not display sex-specific external characteristics year-round. However, during the reproductive period, male arapaima scales are redder, especially near the jaw (Figure 2). Arapaima exhibit unilateral gonadal development, making internal examinations important for sexing and determining ripeness. While sonography can be used for sexing other large fish such as sturgeon in culture settings, it is currently thought to be impractical with arapaima in dispersed semi-intensive culture ponds.

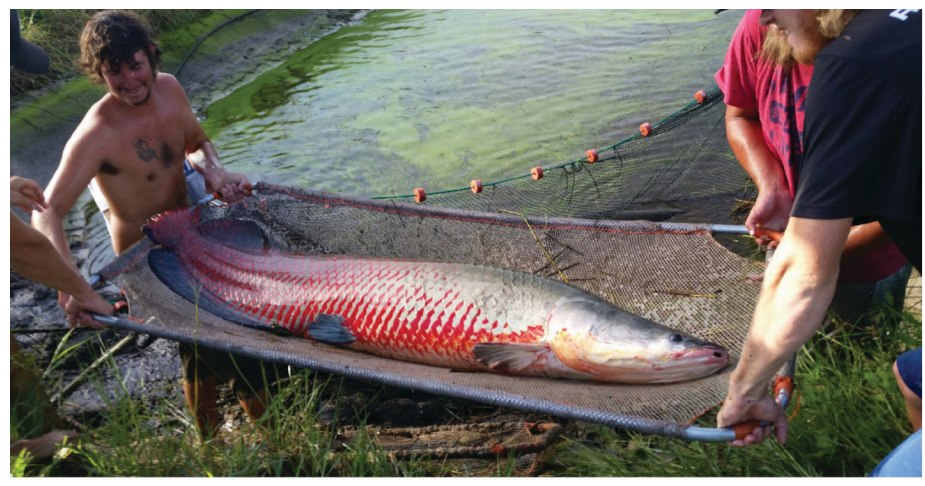

Figure 2. Adult arapaima showing enhanced red coloration during breeding season.

Credits: Carlos Martinez, Horse Creek Aquaculture 
Sex differentiation can also be performed by laparoscopy or using an enzyme immunoassay kit. Laparoscopy has been reported to be an effective and low-stress means of sex differentiation for arapaima (Carreiro et al. 2011). However, laparoscopy is a subjective method to determine sex, and it requires specialized training and equipment. The other method to determine sex in arapaima is collecting blood by caudal puncture and then using an enzyme immune assay (EIA) on the plasma to detect and quantify vitellogenin. Vitellogenin (Vtg) is a protein produced by ripe female arapaima. This is a more objective method of differentiating sex, and adult arapaima were reported to be $100 \%$ accurately sexed using the Vtg EIA. For differentiating sex in immature arapaima, hormone ratios can be used from plasma (specifically 17B-estradiol and 11-kestosterone) for $100 \%$ accuracy (Chu-Koo et al. 2009).

In addition to sex determination, assessing genetic variability is also important for breeding pair selection to select for fast growers with high fillet yield. Determining the genetic diversity in cultured arapaima using multiplex microsatellite polymerase chain reaction (PCR) has been shown to be efficient and inexpensive (Hamoy et al. 2008). Commercial arapaima operations have the option to combine multiplex PCR with the aforementioned methods to select advantageous breeding pairs.

\section{Feeding and Nutrition of Broodstock}

Arapaima are large carnivorous fish that reach sexual maturity at a late age and large size. This makes nutrition and feeding a challenging aspect of broodstock production. Feeding is the only factor that has been found to significantly increase arapaima breeding success. For extensive and semi-intensive culture schemes, breeding ponds are prepared by thorough drying, liming, and seeding with fertilizer to stimulate zooplankton growth. They are then stocked with forage fish, such as tilapia. Feeding regimens can vary greatly between farms and may include fish and chicken products, pelleted fish feed, and sometimes even fruit (Nuñez et al. 2011). Some producers are using marine fish feed with: $50 \%$ crude protein, $14 \%$ crude fat, $3 \%$ crude fiber, and $1.2 \%$ phosphorous (C. Martinez, personal communication). Further research is required to determine specific nutritional requirements for arapaima broodstock and to develop more standardized feeding regimens.

\section{Nursery}

Once spawns occur, there are two options: remove the eggs, or leave them under the care of adults in the pond. The primary constraint on nursery production of fingerlings in tanks is the need to feed live food until the arapaima are large enough to acclimate to prepared foods. Eggs can be removed from the nest, but parental care by aggressive adult fish and the adhesiveness of the egg masses can cause issues (C. Martinez, personal communication).

Artificial incubation techniques are seldom used in arapaima culture. However, the Research Institute of the Peruvian Amazon has developed an arapaima egg basket. Continuous agitation of the basket mimics parental egg care. After egg masses are removed from nests, they are incubated in the baskets until larvae hatch in 18 to 24 hours, depending on water temperature. Upon hatching, larvae are approximately $11.6 \mathrm{~mm}$ ( 0.5 inches) long and retain their yolk sacs for eight to nine days (Guerra et al. 2002).

Currently, the most common fingerling production method is parental care in the breeding ponds. Pond fertilization prior to the breeding season ensures ample plankton blooms to feed the fingerlings. Fingerling presence is confirmed by observing juvenile arapaima air breathing at the pond surface, which occurs approximately every 45 seconds (Figure 3). At two to four weeks old (approximately $10 \mathrm{~cm} / 4$ inches), fingerlings can be separated from their parents with seine nets and transferred into tanks, ponds, or raceways, where they are trained to consume prepared diets (Figures 4 and 5). Arapaima fingerlings are not cannibalistic and can have very high survival rates in the absence of external predation, infection, or poor water quality. Recommended nursery stocking densities are summarized in Table 2.

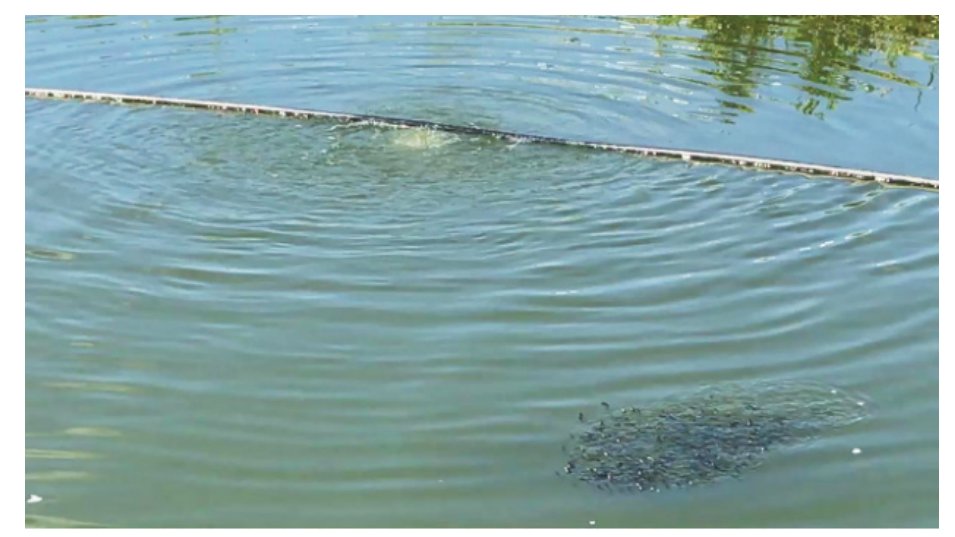

Figure 3. Arapaima fingerlings breathing at the surface of a pond. Credits: Carlos Martinez, Horse Creek Aquaculture 


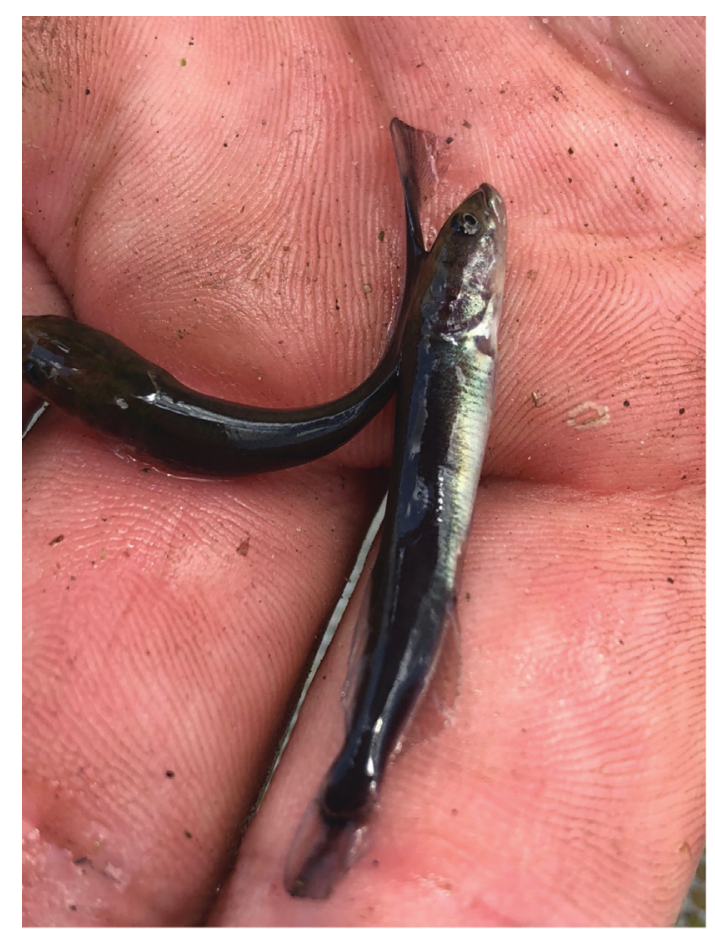

Figure 4. Arapaima fingerlings.

Credits: Carlos Martinez

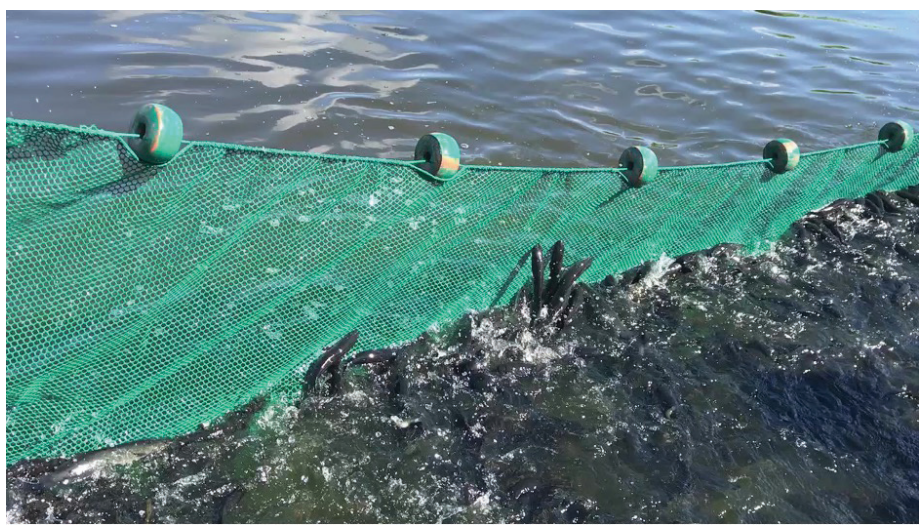

Figure 5. Using a seine to remove arapaima fingerlings from a pond. Credits: Carlos Martinez

\section{Feeding and Nutrition of Fingerlings}

Arapaima fingerling nutrition is a very active area of research. Generally, the nursery feeding regimen begins with feeding live foods at frequent intervals. The smallest fingerlings are fed Artemia nauplii, cultured zooplankton, or a combination. Since arapaima fingerlings filter feed, survival and feeding efficiency may be increased by stocking them at densities that facilitate shoaling (Figure 6). Fingerlings acclimated to live food are trained to accept prepared feed, using one of several approaches to "weaning," including introducing small forage fish, such as guppies Poecilia reticulata, manufacturing a semi-moist feed from the forage fish on-site, or using commercial feeds. After weaning, Florida producers have reported that arapaima readily accept pelleted feed for their lifetime. There is currently no commercial fish feed marketed specifically for arapaima fingerlings, but other commercially available diets may be sufficient. Specific nutritional requirements for arapaima fingerlings have not yet been definitively established (Table 3 ). While this is an active field of research, additional research is needed to establish more standardized arapaima fingerling feeding regimens.

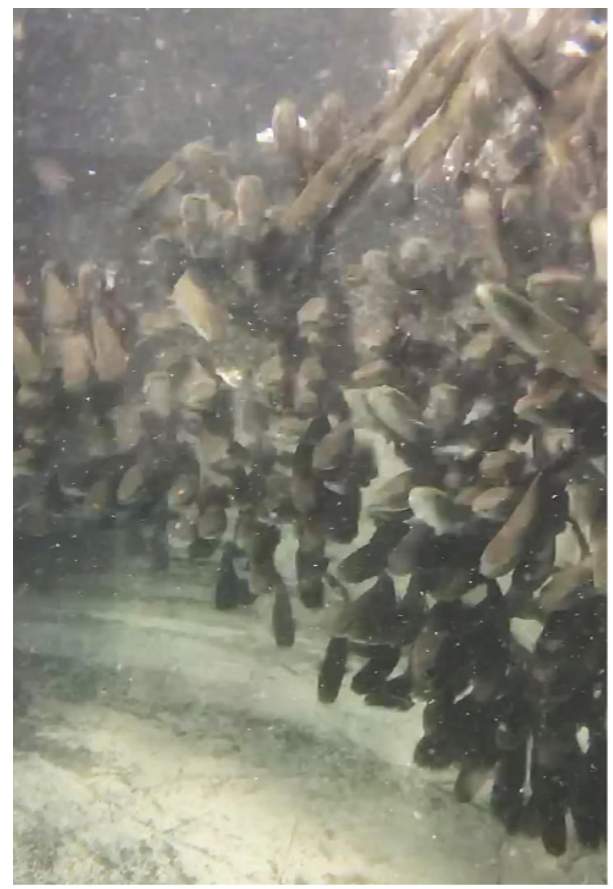

Figure 6. Shoal of arapaima fingerlings in tanks exhibiting collective feeding.

Credits: Carlos Martinez

\section{Growout}

Only limited specific information is available regarding growout practices. Arapaima in the growout phase are robust and tolerant of vigorous handling and high stocking densities, but production can be inconsistent due to the developing nature and remote location of the culture areas. Arapaima growout operations in South America are generally non-intensive, beginning with four-month-old juveniles in ponds, or semi-intensive in cage systems in lakes and reservoirs. There have been limited trials using intensive recirculating systems for the growout phase. Arapaima remain in the growout phase for approximately nine months until reaching approximately $10-15 \mathrm{~kg}(22-33$ pounds).

There is great variation in system configurations for growout. Ponds can be as small as 2,500 $\mathrm{m}^{2}$ (26909.78 square feet) of surface area and $0.8 \mathrm{~m}$ (2.6 feet) in depth. They can be static or have a flowing water supply. Little information is available regarding water parameters for arapaima growout. In general, arapaima should be maintained within the parameters outlined in Table 1. 
Inventorying arapaima during growout in extensive pond culture settings can be challenging. Commercial aquaculture facilities use the obligate air breathing of arapaima to count their fish. Well-trained staff can count fish when they come to the surface to breathe (Castello 2004). This counting method is cost-effective because it negates the need for re-capture, decreasing the stress of the fish and allowing for management decisions to be made more quickly (Castello 2004).

Currently, the market size for arapaima in South America is $10-15 \mathrm{~kg}$ (22-33 pounds) and $110-120 \mathrm{~cm}$ (43-47 inches) (Nuñez 2012). They reach this size after approximately twelve months of age, depending on feeding intensity. At harvest, fish are generally captured with seine nets, euthanized by immersion in cold water, bled, and eviscerated. The fish are filleted, vacuum-packed, and frozen for export. The resulting fillets are $50-55 \%$ of the arapaima's pre-harvest body weight.

\section{Feeding and Nutrition during Growout}

Nutrition is the most studied aspect of arapaima growout, but information is still limited. A commercial feed formulated specifically for arapaima is available in Peru for USD \$1.50-2.00 per kg (\$3.30-4.40 per pound). Fish fed the diet have a FCR of $\sim 1.8$ to 2.0 (Nuñez 2012). This feed consists of $55 \%$ protein and $14 \%$ lipid for smaller fish and decreases to $45 \%$ protein and $12 \%$ lipid for growout. Arapaima in cage culture have been reported to achieve maximum growth when fed a crude protein level of $48.6 \%$. Investigations of feed formulations have shown that the highest apparent digestibility coefficients for crude fat were obtained with soybean oil, which may be used to replace fish oil (Ono et al. 2008). Nutrition research is ongoing, and the high cost of feed and the high protein requirements are an important economic consideration for the development of arapaima aquaculture.

\section{Health}

Arapaima obligate air breathing requires special health management considerations to ensure that arapaima do not drown during handling, especially under anesthesia and when separating fingerlings from adults (Gomes et al. 2006). Anecdotally, the authors have had challenges with algae and mud blocking air flow in the pneumatic duct while the fish are in a net. Therefore, caution should be used when moving fish if mud and algae are present.

Water quality management should not be neglected in arapaima aquaculture, despite their ability to tolerate much lower levels of dissolved oxygen than other fish.
Arapaimamay not show signs of ill health in the same manner or as quickly as other fish species. Low water temperature $\left(<24^{\circ} \mathrm{C}\right)$ can impede arapaima growth, and high water temperature $\left(>32^{\circ} \mathrm{C}\right)$ can increase arapaima's susceptibility to disease. Environmental diseases of arapaima have not been thoroughly studied. However, juvenile arapaima were reported to have a high tolerance for ammonia, with 100\% survival at $25 \mathrm{mg} / \mathrm{L}$ total ammonia (Cavero et al.2004). In this instance, though, unionized ammonia (UIA) was not reported separately, and it should be kept in mind that many fish can tolerate high total ammonia concentrations if UIA is low.

\section{Disease and Parasites}

Diseaseand parasites are significant challenges inarapaima aquaculture, and accumulation of knowledge of commonpathogens is ongoing. Fingerlings, especially at very early stages, are the most susceptible to catastrophic loss due to infections. Arapaima fingerlings have been reported to be susceptible to infection from nematodes (Goezia spinulosa), monogenea (Dawstrema cycloancistroides), and bacteria (Aeromonas hydrophila). Juveniles have higher survival and are less susceptible to infections compared to fingerlings (Nuñez 2012). Seasonal stressors, especially when the water temperature is $>32^{\circ} \mathrm{C}\left(89.6^{\circ} \mathrm{F}\right)$, can trigger metabolic changes in captive arapaima and can increase disease susceptibility and cause temporary interruption of growth (Bezerra et al. 2013). Arapaima are susceptible to Aeromonas hydrophilia bacteria, which causes ulcers and hemorrhages. A study of necropsied arapaima fingerlings from a semi-intensive aquaculture facility in Brazil found that $96 \%$ of the necropsied arapaima were host to parasites, including monogeneans, nematodes, protozoans, and metazoans (Araujo et al. 2009). Monogenea, including Dawstrema cycloancistrium and Dawstrema cycloancistroides, and ciliates, including Trichodina fairai, are reported to be the most persistent parasites of cultured arapaima in Brazil (Araujo et al. 2009; Matthews et al. 2014).

\section{Markets}

Currently, the main market for arapaima is highendrestaurants with a market value of \$12-15 per kg (\$26.40-33.00 per pound) in South America and \$20-25 per kg ( $\$ 44.00-55.00$ per pound) in the United States and Europe. The majority of arapaima aquaculture is in South America, although export volumes are low.

Arapaima meat marketed and consumed locally in South America is processed into fillets that are vacuum packed and frozen or may be salted (Nuñez 2012). A portion 
of harvested arapaima meat may be smoked for local consumption or export (de Quiroz 2000). In 2013, Whole Foods began selling cultured arapaima from Peru (referred to as "paiche") as a cheaper alternative to Pacific halibut (Hippoglossus stenolepis) or Chilean sea bass (Dissostichus eleginoides). The campaign received media coverage across the United States, and today recipes can be found for paiche tacos, salads, etc., allowing arapaima to successfully transition from a delicacy to an everyday protein source for the modern consumer.

There are also smaller markets for arapaima skins, and scales and are used for art, belts, and jewelry. Arapaima skins are used primarily in the manufacture of Western boots marketed in the United States by Lucchese Bootmaker and Rocky Brands, Inc. under the brand Durango Boots.

From the economic perspective of the producer, there are high up-front costs forarapaima production, including acquiring and maintaining the broodstock and setting up the hatchery and growout ponds. However, arapaima growquickly and reach market size in the first year, which allows for annual sales and cash flow. Arapaima are a promising potential fish for commercial aquaculture. There are markets and apparent high demand for arapaima produced by aquaculture in south Florida.

\section{Conclusion}

There is extensive knowledge of arapaima aquaculture becauseof the economic and ecological importance of this species in South America. However, the knowledge and practice of arapaima aquaculture in other regions has been limited, due to the developing nature of South Americaand the complicated conservation status of the fish. Arapaima aquaculture is an active area of research and shows potential for expanded sustainable development. Despite being large, carnivorous, and reaching sexual maturity at a late age, arapaima adapt well to prepared diets, grow quickly, and reach market size in the first year, which allows for annual cash flow from sales. While Peruvian and Brazilian producers successfully grow market-size arapaima, production bottlenecks contribute to limited availability of fingerlings and meat. Conservation issues for arapaima are primarily related to the biodiversity, culture, and economy of the Amazon River basin. The main concerns for Florida producers are the CITES Appendix II trade restrictions and the potential for invasion of Florida waterways. It might be difficult to obtain broodstock due to trade restrictions, state and federal regulations, and transport logistics. Several aspects of arapaima husbandry require further research, including specific nutrition requirements for all culture stages, more standardized feeding regimens, greater understanding of environmental diseases, and the feasibility of intensive culture. Disease is a challenge in arapaima aquaculture, though preventable with proper care. Currently, the main market for arapaima is high-end restaurants, but the market is expanding. There are high up-front costs for arapaima production; however, there is potential to offset costs quickly, as fish are market size within a year. Overall, establishing arapaima aquaculture in Florida is not without challenges, but presents a potential significant economic opportunity for the innovative producer.

\section{References}

Araújo, C. S. O., A. L. Gomes, M. Tavares-Dias, S. M. S. Andrade, A. Belem-Costa, J. T. Borges, M. Queiroz, and M. Barbosa. 2009. "Parasitic Infections in Pirarucu Fry, Arapaima gigas Schinz, 1822 (Arapaimatidae) Kept in a Semi-Intensive Fish Farm in Central Amazon, Brazil." Veterinarski Arhiv 79:499-507.

Arantes, C., L. Castello, M. Cetra, and A. Schilling. 2013. "Environmental Influences on the Distribution of Arapaima in Amazon Floodplains." Environmental Biology of Fishes 96:1257-1267.

Bezerra, R. F., M. D. C. F. Soares, A. J. G. Santos, E. M. Carvalho, and L. C. B. Coelho. 2013. "Secondary Indicators of Seasonal Stress in the Amazonian Pirarucu Fish (Arapaima gigas)." Advances in Environmental Research 28:233-244.

Carreiro, C. R. P., M. A. D. A. Furtado-Neto, P. E. C. Mesquita, and T. A. Bezerra. 2011. "Sex Determination in the Giant fish of Amazon Basin, Arapaima gigas (Osteoglossiformes, Arapaimatidae), Using Laparoscopy." Acta Amazonica 41:415-419.

Cavero, B. A. S., M. A. M. Pereira-Filho,F. A. L. D. Bordinhon, D. Fonseca, D. R. Ituassú, R. Roubach, and E. A. Ono. 2004. "Tolerance of Pirarucu Juveniles to Increasing Ammonia Concentration in a Closed Environment.' Pesquisa Agropecuária Brasileira 39:513-516.

Chu-Koo, F., R. Dugué, M. A. Aguilar, A. C. Daza, F. A. Bocanegra, C. C. Veintemilla, and J. Nunez. 2009. "Gender Determination in the Paiche or Pirarucu (Arapaima gigas) Using Plasma Vitellogenin, 17ß-estradiol, and 11-ketotestosterone Levels." Fish Physiology and Biochemistry 35:125-136. 
Gomes, L. C., E. C. Chagas, R. P. Brinn, R. Roubach, C. E. Coppati, and B. Baldisserotto. 2006. "Use of Salt during Transportation of Air Breathing Pirarucu Juveniles (Arapaima gigas) in Plastic Bags." Aquaculture 256:521-528.

Guerra, H., F. Alcántara, P. Padilla, M. Rebaza, S. Tello, R. Ismiño, and L. Limachi. 2002. "Manual Para la Producción y Manejo de Alevinos de Paiche.” Instituto de Investigaciones de la Amazonía Peruana, IIAP.

Hamoy, I. G., E. J. M. Santos, and S. E. B. Santos. 2008. "Rapid and Inexpensive Analysis of Genetic Variability in Arapaima gigas by PCR Multiplex Panel of Eight Microsatellites." Genetics and Molecular Research 7:29-32.

Hill, J. E., and K. M. Lawson. 2015. "Risk Screening of Arapaima, a New Species Proposed for Aquaculture in Florida." North American Journal of Fisheries Management $35: 885-894$.

Lawson, L. L., Q. M. Tuckett, K. M. Lawson, C. A. Watson, and J. E. Hill. 2015. "Lower Lethal Temperature for Arapaima Arapaima gigas: Potential Implications for Culture and establishment in Florida." North American Journal of Aquaculture 77:497-502.

Matthews, D. P., O. Ismiño, and A. F. Malheiros. 2014. "High infection of Nilonema senticosum in Mature Arapaima gigas Cultivated in the Peruvian Amazon." Revista de Investigaciones Veterinarias del Perú (RIVEP) 25:414-418.

Nuñez, J. 2012. "Cultured Aquatic Species Information Programme: Arapaima gigas." Food and Agriculture Organization of the United Nations.

Núñez, J., F. Chu-Koo, M. Berland, L. Arévalo, O. Ribeyro, F. Duponchelle, and J. F. Renno. 2011. "Reproductive Success and Fry Production of the Paiche or Pirarucu, Arapaima gigas (Schinz), in the Region of Iquitos, Perú." Aquaculture Research 42:815-822.

Ono, E. A., É. D. S. S.Nunes, J. C. C. Cedano, M. Pereira Filho, and R. Roubach. 2008. "Apparent Digestibility Coefficient of Practical Diets with Different Energy: Protein Ratios for Pirarucu Juveniles." Pesquisa Agropecuária Brasileira 43:249-254.

de Queiroz, H. L. D. 2000. "Natural History and Conservation of Pirarucu, Àrapaima gigas, atthe Amazonian Várzea: Red Giants in Muddy Waters." University of St Andrews.
Rebouças, P. M., R. L. Maciel, B. G. B. Costa, J. A. S. Galvão, and J. A. D. Barbosa Filho. 2014. "Análise do bem-estar dos reprodutores de Arapaima gigas (Schinz, 1822) através da relação peso-comprimento, fator de condição e produção de alevinos." Bioscience Journal 30:873-881.

\section{Additional Readings}

Alcantara, B., M. Tello, V. Chavez, C. Rodriguez, C. C. Kohler, S. T. Kohler, and N. Camargo. 2004. "Pond Culture of Arapaima gigas in the Peruvian Amazon." World Aquaculture Magazine 35:45-46.

de Andrade, J. I. A., E. A. Ono, G. C. de Menezes, E. M. Brasil, R. Roubach, E. C. Urbinati, M. Tavares-Dias, J. L. Marcon, and E. G. Affonso. 2007. "Influence of Diets Supplemented with Vitamins C and E on Pirarucu (Arapaima gigas) Blood Parameters."

Comparative Biochemistry and Physiology Part A: Molecular \& Integrative Physiology 146:576-580.

Augusto, F. J., H. M. S. Costa, M. Y. Icimoto, I. Y. Hirata, M. Marcondes, L. B. Carvalho, V.Oliveira, and R. S. Bezerra. 2012. "Giant Amazonian Fish Pirarucu (Arapaima gigas): Its Viscera as a Source of Thermostable Trypsin." Food Chemistry 133:1596-1602.

Berra, T. M. 2001. Osteoglossidae-Bonytongues. In Freshwater Fish Distribution. Edited by T. M. Berra, p. 55. Academic Press, San Diego, California.

Bezerra, R. F., M. C. C. F. Soares, A. J. G. Santos, E. V. M. Maciel Carvalho, and L. C.B. Coelho. 2014. "Seasonality Influence on Biochemical and Hematological Indicators ofStress and Growth of Pirarucu (Arapaima gigas), an Amazonian Air-BreathingFish." The Scientific World Journal $14: 1-6$

Bocanegra, F. A., W. Wust, S. T. Martín, M. R. Alfaro, and D. D. C. Torres. 2006. "Paiche: El gigante del Amazonas" Instituo de Investigaciones de la Amazonia Peruana. 7-55

Cardoso, G. C. 2015. Taxas de arraçoamento sobre desempenho produtivo e econômico de alevinos de pirarucu (Arapaima gigas) de 500 a $1000 \mathrm{~g}$ cultivado em hapas.

Castello, L. 2004. "A Method to Count Pirarucu Arapaima gigas: Fishers, Assessment, and Management." North American Journal of Fisheries Management 24:379-389. 
Castello, L. 2008. "Nesting Habitat of Arapaima gigas (Schinz) in Amazonian Floodplains." Journal of Fish Biology 72:1520-1528.

Castello, L. 2008a. Lateral migration of Arapaima gigas in floodplains of the Amazon. Ecology of Freshwater Fish 17:38-46.

Castello, L. 2008b. "Nesting Habitat of Arapaima gigas (Schinz) in Amazonian Floodplains." Journal of Fish Biology 72:1520-1528.

Castello, L., and D. J. Stewart. 2010. "Assessing CITES NonDetriment Findings Procedures for Arapaima in Brazil." Journal of Applied Ichthyology 26:49-56.

Castello, L., D. J. Stewart, and C. C. Arantes. 2011. "Modeling Population Dynamics and Conservation of Arapaima in the Amazon." Reviews in Fish Biology and Fisheries 21:623-640.

Castello, L., J. P. Viana, G. Watkins, M. Pinedo-Vasquez, and V. A. Luzadis. 2009. "Lessons from Integrating Fishers of Arapaima in Small-Scale Fisheries Management at the Mamirauá Reserve, Amazon." Environmental Management 43:197-209.

Cavero, B. A. S., D. R. Ituassú, M. Pereira Filho, R. Roubach, A. M. Bordinhon, F. A. L. daFonseca, and E. A. Ono. 2003c. "Uso de alimento vivo como dieta inicial no treinamento alimentar de juvenis de pirarucu." Pesquisa Agropecuária Brasileira 38:1011-1015.

Cavero, B. A. S., M. Pereira-Filho, R. Roubach, D. R. Ituassú, A. L. Gandra, and

R. Crescêncio. 2003a. Sustainable Biomass of Pirarucu Juveniles in Small Volume Net Cages." Pesquisa Agropecuária Brasileira 38:723-728.

Cavero, B. A. S., M. Pereira-Filho, R. Roubach, D. R. Ituassú, A. L. Gandra, and R. Crescêncio. 2003b. "Stocking Density Effect on Alimentary Efficiency in JuvenilePirarucu (Arapaima gigas) in a Confined Environment." Acta Amazonica 33:631-636.

Delgado, P. M., J. P. Delgado, and R. I. Orbe. 2013. "Parasitic Infections in Juveniles of Arapaima gigas (Schinz, 1822) Cultivated in the Peruvian Amazon." Annals of Parasitology 59:43-48.
Dias, M. K. R., L. S. Sampaio, A. A. Proietti-Junior, E. T. Yoshioka, D. P. Rodrigues, A. F. Rodriguez, R. A. Ribeiro, F. S. Faria, R. O. Ozório, and M. Tavares-Dias. 2016. "Lethal Dose and Clinical Signs of Aeromonas hydrophila in Arapaima gigas (Arapaimidae), the Giant Fish from Amazon." Veterinary Microbiology 188:12-15.

Drumond, G. V. F., A. P. Caixeiro, M. Tavares-Dias, J. L. Marcon, and E. G. Affonso. 2010. "Características bioquímicas e hematológicas do pirarucu Arapaima gigas Schinz, 1822 (Arapaimidae) de cultivo semi-intensivo na Amazônia." Acta Amazônica 40:591-596.

Duncan, W. P., and M. N. Fernandes. 2010. "Physicochemical Characterization of the White, Black, and Clearwater Rivers of the Amazon Basin and Its Implications on the Distribution of Freshwater Stingrays (Chondrichthyes, Potamotrygonidae)." Journal of Aquatic Science 5:454-464.

Figueiredo, E. 2013. "Biologia, conservação e manejo participativo de pirarucus na PanAmazônia." Instituto de Desenvolvimento Sustentável Mamirauá.Gandra, A. L., D. R. Ituassú, M. Pereira-Filho, R. Roubach, R. Crescêncio, and B. A. Cavero. 2007. "Pirarucu Growth under Different Feeding Regimes.” Aquaculture International15:91-96.

Godinho, H. P., J. E. Santos, P. S. Formagio, and R. J. Guimarães-Cruz. 2005. "Gonadal Morphology and Reproductive Traits of the Amazonian fish Arapaima gigas (Schinz, 1822)." Acta Zoologica 86:289-294.

Godinho, H. M., N. Fenerich, N. Y. Narahara, and J.M.B. Barker. 1977. "Sobre a reprodução induzida do Pacú, Colossoma mitrei (Berg, 1885)." Ciênciae Cultura 29:796-797.

Gomes, L. D. C. 2007. "Physiological Responses of Pirarucu (Arapaima gigas) to AcuteHandling Stress." Acta Amazonica 37:629-633.

Gomes, L. D. C., R. Roubach, B. A. S. Cavero, M. Pereira-Filho, and E. C. Urbinati. 2003. "Transport of Pirarucu Arapaima gigasJuveniles in Plastic Bag." Acta Amazonica 33:637-642.

Green, A. 2006. “Arapaima gigas Market Study Current Status of Arapaima Global Trade and Perspectives on the Swiss, French and UK Markets." United Nations Conference on Trade and Development. UNCTAD. 
Greenwood, P. H., and K. F. Liem. 1984. Aspiratory respiration in Arapaima gigas (Teleostei, Osteoglossomorpha): A reappraisal. Journal of Zoology 203:411-425.

Groff, A. A., J. da Silva, E. A. Nunes, M. Ianistcki, T. N. de Oliveira, C. P. Feitosa de Oliveira, A. L. Val, and J. A. P. Henriques. 2010. "UVA/UVB-Induced Genotoxicity and Lesion Repair in Colossoma macropomum and Arapaima gigas Amazonian Fish. Journal of Photochemistry and Photobiology B: Biology 99:93-99.

Honczaryk, A., and L. Inoue. 2010. "Anestesia do pirarucu por aspersão da benzocaína diretamente nas brânquias." CiênciaRural 40:204-207.

Honczaryk, A., and L. A. K. A. Inoue. 2009. "Anestesia do pirarucu por aspersão direta nas brânquias do eugenol em solução aquosa."CiênciaRural 39:577-579.

Hrbek, T., M. Crossa, and I. P. Farias. 2007. Conservation Strategies for Arapaima gigas (Schinz, 1822) and the Amazonian Várzea Ecosystem." Brazilian Journal of Biology 67:909-917.

Hrbek, T., I. P. Farias, M. Crossa, I. Sampaio, J. I. Porto, and A. Meyer. 2005. "Population Genetic Analysis of Arapaima gigas, One of the Largest Freshwater Fishes of the Amazon Basin: Implications for its Conservation." Animal Conservation 8:297-308.

Imbiriba, E. P. 2001. "Potencial de Criacao de Pirarucu, Arapima gigas, em Cativeiro.” Acta Amazonica 31:299-316.

Ituassú, D. R., M. Pereira-Filho, R. Roubach, R. Crescêncio, B. A. S. Cavero, and A. L. Gandra. 2005. "Níveis de proteína bruta para juvenis de pirarucu." Pesquisa Agropecuária Brasileira 40:255-259.

Junk, W. J. 2001. "Sustainable Use of the Amazon River Floodplain: Problems and Possibilities." Aquatic Ecosystem Health \& Management 4:225-233.

Kritsky, D. C., W. A. Boeger, and V. E. Thatcher. 1985. "Neotropical Monogenea. 7. Parasites ofthe Pirarucu, Arapaima gigas (Cuvier), with Description of Two New Species and Redescription of Dawestrema cycloancistrium Price and Nowlin, 1967 (Dactylogyridae: Ancyrocephalinae)." Proceedings of the Biological Society of Washington 98:321-331.
Lima, A. F., A. P. O. Rodrigues, P. Maciel, F. Rezende, L. E. L. de Freitas, M. Tavares-Disse, and T. Bezerra. 2017. "Alevinagem, recria e engorda de pirarucu." Jornal de Brasilia 152.

Marinho, R. G. B., M. Tavares-Dias, M. K. R. Dias-Grigório, L. R. Neves, E. T. O. Yoshioka, C. D. L. Boijink, and R. M. Takemoto. 2013. "Helminthes and Protozoan of Farmed Pirarucu (Arapaima gigas) in Eastern Amazon and HostParasite Relationship." Arquivo Brasileiro de Medicina Veterinária e Zootecnia 65:1192-1202.

Marques, D. K., P. C. Venere, and P. M. Galetti Junior. 2006. "Chromosomal Characterization of the Bonytongue Arapaima gigas (Osteoglossiformes: Arapaimidae)." Neotropical Ichthyology 4:215-218.

de Mattos, B. O., E. C. T. Nascimento Filho, K. A. Barreto, L. G. T. Braga, and R. Fortes-Silva. 2016. "Self-Feeder Systems and Infrared Sensors to Evaluate the Daily Feeding and Locomotor Rhythms of Pirarucu (Arapaima gigas) Cultivated in Outdoor Tanks." Aquaculture 457:118-123.

McDaniel, J. 1997. "Communal Fisheries Management in the Peruvian Amazon.” Human Organization 56:147-152.

de Menezes, G. C., M. Tavares-Dias, E. A. Ono, J. I. A. de Andrade, E. M. Brasil, R. Roubach, E. C. Urbinati, J. L. Marcon, and E. G. Affonso. 2006. "The Influence of Dietary Vitamin C and E Supplementation on the Physiological Response of Pirarucu, Arapaima gigas, in Net Culture. Comparative Biochemistry and Physiology Part A: Molecular \& Integrative Physiology 145:274-279.

Mendoza, R., S. Luna, and C. Aguilera. 2015. "Risk Assessment of the Ornamental Fish Trade in Mexico: Analysis of Freshwater Species and Effectiveness of the FISK (Fish Invasiveness Screening Kit). Biological Invasions 17(12): 3491-3502.

Meske, C. 1980. "Erfahrungsbericht iiher die Aufzucht von tropischen Warmwasserfischen in Ahrenshurg." Arbeiten des Deutschen Fischerei-Verbaendes 30:109-122.

Migdalski, E. C. 1957. "Contribution to the Life History of the South American Fish Arapaima gigas." Copeia 1:54-56.

Miranda-Chumacero, G., R. Wallace, H. Calderón, G. Calderón, P. Willink, M. Guerrero, andD. Chuqui. 2012. "Distribution of Arapaima (Arapaima gigas) (Pisces: Arapaimatidae) in Bolivia: Implications in the Control and Management of a Non-Native Population." BioInvasions Records 2:129-138. 
Monteiro, L. B. B., M. C. F. Soares, M. T. J. Catanho, and A. Honczaryk. 2010. "Reproductive Aspects and Sexual Steroids Hormonal Profiles of Pirarucu, Arapaima gigas (SCHINZ, 1822), in Captivity Conditions." Acta Amazônica 40:435-450.

Mueller, O., and A. Green. 2005. "Arapaima gigas Market Study: Current Status of Arapaima Global Trade and Perspectives on the Swiss, French and UK Markets." Cocha El Dorado: NCTAD.

Nelson, J. S. 1994. Fishes of the World, 3rd edition. New York, NY: John Wiley and Sons, Inc.Nijman, V. 2010. "An Overview of International Wildlife Trade from Southeast Asia." Biodiversity and conservation 19(4): 1101-1114.

de Oliveira, E. G., A. B. Pinheiro, V. Q. de Oliveira, A. R. M. da Silva, M. G. de Moraes, Í. R. C. B.Rocha, and F. H. F. Costa. 2012. "Effects of Stocking Density on the Performance of Juvenile Pirarucu (Arapaima gigas) in Cages." Aquaculture 370:96-101.

de Oliveira, V. D., S. L. Poleto, and P. C. Venere. 2005. "Feeding of Juvenile Pirarucu (Arapaima gigas, Arapaimidae) in Their Natural Environment, Lago Quatro Bocas, Araguaiana-MT, Brazil." Neotropical Ichthyology 3:312-314.

de Oliveira, V. Q., A. R. B. Matos, T. A. Bezerra, P. E. C. Mesquita, A. M. de Moraes, and F. H. F. Costa. 2013. "Preliminary Studies on the Optimum Feeding Rate for Pirarucu Arapaima gigas Juveniles Reared in Floating Cages." International Journal of Aquaculture 3:147-151.

Ono, E. A., M. R. Halverson, and F. Kubitza. 2004. "Pirarucu o gigante esquecido." Panorama da Aqüicultura $14: 14-25$.

Ono, E.A., R. Roubach, and M. F. Pereira. 2003. "Pirarucu Production-Advances in Central Amazon, Brazil." Global Aquaculture Advocate 6:44-46.

Parker, B. H. 2002. "Arapaima: An Amazonian Fish Species of Immense Proportions." Biodiversity 3(2): 21-24.

Pereira-Filho, M., B. A. S. Cavero, R. Roubach, D. R. Ituassú, A. L. Gandra, and R. Crescêncio. 2003. "Cultivo do pirarucu (Arapaima gigas) em viveiro escavado." Acta Amazonia 33:715-718

Ramos, C. A., J. C. N. Raulino, G. C. de Menezes, I. B. do Carmo, E. M. Brasil, E. G. Affonso, and M. Narciso. 2014. "Influences of Amazonian White and Black Waters on the Hematological and Biochemical Plasma Features of Arapaima gigas (Osteoglossiformes)." Journal of Life Sciences 8:252-261.

Rebouças, P. M., J. A. D. Barbosa Filho, M. C. da Silva, C. B. do Nascimento, M. D. V. Queiroz, and J. A. S. Galvão. 2012. "Length-Weight Relationship and Condition Factor (kn) in the Reproductive Period of Arapaima gigas (Schinz, 1822) in Captivity." Ciência Animal 22:722-724.

Ribeiro, R. A., R. O. D. A. Ozório, S. M. G. Batista, M. Pereira-Filho, E. A. Ono, and R. Roubach. 2011. "Use of Spray-Dried Blood Meal as an Alternative Protein Source in Pirarucu (Arapaima gigas) Diets." Journal of Applied Aquaculture 23:238-249.

Saint-Paul, U. 1986. "Potential for Aquaculture of South American Freshwater Fishes: A Review." Aquaculture 54:205-240.

dos Santos, C. H. D. A. 2014. "Genetic Relationships between Captive and Wild Subpopulations of Arapaima gigas (Schinz, in Cuvier, 1822). International Journal of Fisheries and Aquaculture 6:108-123.

Santos, C. P., and F. Moravec. 2009. “Tissue-Dwelling Philometrid Nematodes of the Fish Arapaima gigas in Brazil." Journal of Helminthology 83:295-301.

Serrano-Martínez, E., P. Castro, H. Quispe, V. Casas, and Q. León. 2014. "Isolation of Bacteria and Fungi in Tissues of Paiche (Arapaima gigas) Reared in Captivity." Revista de Investigaciones Veterinarias del Perú (RIVEP) 25:117-122.

Stewart, D. J. 2013a. "Re-Description of Arapaima agassizii (Valenciennes), a Rare Fish from Brazil (Osteoglossomorpha: Osteoglossidae)." Copeia 2013:38-51.

Stewart, D. J. 2013b. "A New Species of Arapaima (Osteoglossomorpha: Osteoglossidae) from the Solimões River, Amazonas State, Brazil." Copeia 2013:470-476.

Tavares-Dias, M., J. F. M. Barcellos, J. L. Marcon, G. C. Menezes, E. A. Ono, and E. G. Affonso. 2007. "Hematological and Biochemical Parameters for the Pirarucu Arapaima gigas Schinz, 1822 (Osteoglossiformes, Arapaimatidae) in Net Cage Culture." Electronic Journal of Ichthyology 2:61-68.

Torati, L.S., A. P. S. Varges, J. A. S. Galvão, P. E. C. Mesquita, and H. Migaud. 2016. Endoscopy Application in Broodstock Management of Arapaima gigas (Schinz, 1822)." Journal of Applied Ichthyology 32:353-355. 
Von Sengbusch, R., G. Von Sengbusch, C. Meske, and O. Cellarius. 1974."Domestikations-versuche von Fischarten aus äquatornahen Gebieten zur Prüfung ihrer Eingnung für die Warmwasser-Intensivhaltung Tierzüchter." Der Tierzüchter 5:2.

Watson, L. C. 2011. Ecology and Conservation of Arapaima in Guyana: Recovery of a Giant Fish in Distress. State University of New York College of Environmental Science and Forestry, New York.

Watson, L. C., D. J. Stewart, and M. A. Teece. 2013.

"Trophic Ecology of Arapaima in Guyana: Giant Omnivores in Neotropical Floodplains."Neotropical Ichthyology 11:341-349.

World Conservation Monitoring Centre. 1996. Arapaima gigas. The IUCN Red List of Threatened Species. 
Table 1. Water quality parameters for arapaima. Please note that observed ranges include measurements for both wild and culturedarapaima. Sources: Cavero et al. 2004; Duncan \&; Fernandes 2010; Nuñez et al. 2011; de Quiroz 2000; Ramos et al.2014; V. de Olivera et al. 2013; Ituassú et al. 2005; Lima et al. 2017.

\begin{tabular}{|l|c|c|c|c|c|c|c|}
\hline & $\begin{array}{c}\text { Dissolved } \\
\text { oxygen } \\
(\mathbf{m g} / \mathbf{L})\end{array}$ & $\mathbf{C O}_{2}$ (mg/L) & Nitrites (mg/L) & $\begin{array}{c}\text { Total } \\
\text { Ammonia } \\
\text { (mg/L) }\end{array}$ & $\begin{array}{c}\text { pH } \\
\text { Alkalinity } \\
\text { (mg/L) }\end{array}$ & $\begin{array}{c}\text { Temperature } \\
\left({ }^{\circ} \mathbf{C}\right)\end{array}$ \\
\hline Recommended & $>4.0$ & $<20$ & 0 & $<0.05$ & $6.5-8.0$ & $>20$ \\
\hline Observed Range & $0.5-5.8$ & $2-22$ & $0.05-15$ & $0.2-3.0$ & $3.0-9.3$ & $-26-28$ \\
\hline
\end{tabular}

Table 2. Nursery stocking densities for arapaima fingerlings. Sources: a. Guerra et al. 2002; b. Lima et al. 2017.

\begin{tabular}{|c|c|c|}
\hline Size/Age Class & Culture System & Stocking Density \\
\hline $5-7 \mathrm{~cm}(1.9-2.7 \mathrm{in})^{\mathrm{a}}$ & Aquaria, cement tanks, raceways & 1 fish/L \\
\hline $8-11 \mathrm{~cm}(3.1-4.3 \mathrm{in})^{\mathrm{a}}$ & & 1 fish $/ 2.5 \mathrm{~L}$ \\
\hline $12-15 \mathrm{~cm}(4.7-5.9 \mathrm{in})^{\mathrm{a}}$ & & $1 \mathrm{fish} / 5 \mathrm{~L}$ \\
\hline Larvae $^{b}$ & $\begin{array}{l}\text { Circular tank, water column depth no more } \\
\text { than } 40 \mathrm{~cm}\end{array}$ & $6,500 \mathrm{fish} / 1000 \mathrm{~L}$ \\
\hline Up to 10 days old ${ }^{b}$ & $\begin{array}{l}\text { Circular tank, water column depth no more } \\
\text { than } 80 \mathrm{~cm}\end{array}$ & $3,000 \mathrm{fish} / 1000 \mathrm{~L}$ \\
\hline $5 \mathrm{~cm}(1.9 \mathrm{in})^{\mathrm{b}}$ & Circular tank & 2,000 fish/1000L \\
\hline $8 \mathrm{~cm}(3.1 \mathrm{in})^{\mathrm{b}}$ & Circular tank & 1,000 fish/1000L \\
\hline
\end{tabular}

Table 3. Nursery feeding regimens for arapaima fingerlings. Sources: a. Guerra et al., 2002; b. Nuñez 2012; c. E. de Oliveira et al. 2012; d. Cardoso 2015; e. Lima et al., (2017)

\begin{tabular}{|c|c|c|c|}
\hline Age Class & Mass (g) & TL (cm) & Feeding Regimen \\
\hline $9-21$ days old & $5-12$ & $5-15$ & $\begin{array}{l}\text { Zooplankton for the smallest fish } \\
\text { Artemia nauplii: at } 10 \% \text { of mass of } 8-12 \mathrm{~cm} \text { fry, every } 2-3 \text { hours }^{\mathrm{a}}\end{array}$ \\
\hline $\begin{array}{l}\text { First } 5-7 \text { days after removal from } \\
\text { breeding pond }\end{array}$ & 10 & & Concentrated zooplankton, Artemia nauplii to satiation, 8 times dailye \\
\hline 10-20 days old & & $8-12$ & $\begin{array}{l}80 \% \text { live food, } 20 \% \text { marine larval fish extruded pellets } 45 \%-50 \% \text { of crude } \\
\text { protein, } 0.8 \mathrm{~mm} \text { and } 1.5 \mathrm{~mm} \text { granules. Incremental decrease of live feed over } \\
\text { time: } 70 \% \text { live } / 30 \% \text { pellet, etc. } 8 \text { times daily }\end{array}$ \\
\hline 20 days until transfer to growout & & & $45 \%$ crude protein $2 \mathrm{~mm}-2.6 \mathrm{~mm}$ granules, 6 times daily \\
\hline $21-30$ days old & & $15-18$ & $\begin{array}{l}\text { Moist pellet from chopped forage fish mixed dry fish feed } 55 \% \text { crude protein, at } \\
15 \% \text { mass, } 4 \text { times daily }{ }^{b}\end{array}$ \\
\hline$<40$ days old & & & Extruded pellets with $40 \%$ crude protein 3 times daily ${ }^{d}$ \\
\hline \multirow[t]{3}{*}{$40-60$ days } & $40-60 \mathrm{~g}$ & $18-25$ & $5-8 \mathrm{~mm}$ extruded pellets, $55 \%$ protein, $10 \%$ of mass, 3 times daily ${ }^{b}$ \\
\hline & & & $\begin{array}{l}\text { Forage fish (guppies) stocked at } 5 \% \text { mass or balanced feed with } 50 \% \text { crude } \\
\text { protein at } 5 \% \text { of mass }\end{array}$ \\
\hline & & & $\begin{array}{l}\text { TC } 40 ; \text { Purina }{ }^{\circledast} \text {, São Paulo, Brazil, } 40 \% \text { crude protein } 4 \text { times daily, at } 3 \% \text { of mass } \\
\text { tapering to } 2 \% \text { c }\end{array}$ \\
\hline
\end{tabular}

